\title{
KARAKTERISTIK IBU YANG MENGALAMI DEPRESI DALAM KEHAMILAN
}

\author{
Ratu Kusuma \\ Program Studi Profesi Ners STIKes Baiturrahim Jambi \\ Email: ratukusuma1975@gmail.com
}

\begin{abstract}
Depression in pregnancy is a mood disorder with symptoms of feeling sad, more sensitive so easily irritated even to crying, anxiety, lack of hope for the future, sleep disturbances in the form of nightmares or insomnia, decreased appetite, decreased libido, impaired social interaction, tired easily so that they experience interference in carrying out daily activities, impaired memory or difficulty concentrating, even some mothers experience hallucinations that risk the injury to themselves and others around them. Events in the world reached 23\%, Asia 15-20\%, Indonesia 25\%, while in Riau Province around 20\%. The purpose of this study is to identify the characteristics of mothers who experience depression during their pregnancy. It is a descriptive study, with consecutive sampling technique, conducted on 32 trimester II pregnant women (20-27 weeks) in Kecamatan Bangkinangand 22 pregnant women in Kecamatan Tapung I. The measurement of depression was done using Edinburgh postpartum depression scale (EPDS) which was declared valid and reliably used to measure depression in pregnancy. The results showed that the majority of pregnant women who experience depression are at the age of not at risk (20-35 years) as much as 60\%, secondary education (80\%), depression occurs in working mothers and not working each 50\%, multigravida (70.00\%), having 0-3 children, never experiencing abortion (90.00\%), unwanted pregnancy (30.00\%) and there are $10(18.52 \%)$ trimester II pregnant women who experience depression during pregnancy. Depression experienced by pregnant women in Kecamatan Bangkinang and KecamatanTapung I is quite high, this is thought to be caused by maternal age, education, frequency of pregnancy, number of living children and unwanted pregnancy factors because some mothers do not want their pregnancy.
\end{abstract}

Keyword: Characteristic of Pregnant Women; Depressionin Pragnancy

\begin{abstract}
ABSTRAK
Depresi dalam kehamilan adalah gangguan mood dengan gejala berupa perasaan sedih, lebih sensitif sehingga mudah tersinggung bahkan sampai menangis, gelisah, tidak mempunyai harapan terhadap masa depan, gangguan tidur berupa mimpi buruk atau insomnia, penurunan nafsu makan, penurunan libido, gangguan interaksi sosial, mudah lelah sehingga mengalami gangguan dalam melakukan aktifitas sehari-hari, gangguan mengingat atau susah berkonsentrasi, bahkan beberapa ibu mengalami halusinasi sehingga berisiko mencederai diri sendiri dan orang lain disekitarnya. Kejadian di dunia mencapai 23\%, Asia 15-20\%, Indonesia 25\%, sedangkan di Provinsi Riausekitar 20\%. Tujuan penelitian ini adalah mengidentifikasi karekteristik ibu yang mengalami depresi pada masa kehamilannya. Merupakan penelitian deskriptif, dengan teknik consecutivesampling, dilakukan terhadap 32 ibu hamil trimester II (20-27 minggu) di Kecamatan Bangkinang dan 22 ibu hamil Kecamatan Tapung I. Pengukuran depresi dilakukan dengan menggunakan edinburgh postpartum depression scale (EPDS) yang
\end{abstract}


sudah dinyatakan valid dan reliabel digunakan untuk mengukur depresi dalam kehamilan. Hasil penelitian menunjukkan bahwasebagian besar usia ibu hamil yang mengalami depresi adalah berada pada usia tidak berisiko (20-35 tahun) sebanyak 60\%, pendidikan dasar menengah (80\%), depresi terjadi pada ibu bekerja dan tidak bekerja masing-masing $50 \%$, multigravida $(70.00 \%)$, telah memiliki $0-3$ orang anak hidup, tidak pernah mengalami abortus $(90.00 \%)$, kehamilan tidak diinginkan $(30.00 \%)$ dan terdapat 10 (18.52\%) ibu hamil trimester II yang mengalami depresi pada masa kehamilan. Depresi yang dialami ibu hamil di Kecamatan Bangkinang dan Kecamatan Tapung I ini cukup tinggi, hal tersebut diduga disebabkan oleh faktor usia ibu, pendidikan, frekuensi kehamilan, jumlah anak hidup dan faktor kehamilan yang tidak diinginkan karena beberapa ibu tidak menginginkan kehamilannya.

Kata Kunci:Karakteristik Ibu Hamil; Depresi dalam Kehamilan

\section{PENDAHULUAN}

$\begin{array}{cr}\text { Kehamilan } & \text { seharusnya } \\ \text { merupakan kondisi } & \text { yang }\end{array}$ menyenangkan, karena tidak semua wanita yang sudah menikah bisa hamil dan melahirkan. Namun pada sebagian wanita, justru menjadi suatu beban fisik maupun psikologis. Salah satu gangguan psikologis yang banyak dialami ibu hamil adalah depresi. Kejadian di dunia mencapai $23 \%$, Asia 15-20\%, Indonesia 25\%, di Provinsi Riau 20\%. Penelitian Goodman dan Viola (2010) pada Juni 2006-Februari 2007, di Boston Amerika Serikat melaporkan bahwa dari 525 ibu hamil trimester III (>28 minggu) terdapat $23 \%$ yang mengalami depresi dalam masa kehamilan. Penelitian Nursanti (2012) melaporkan bahwa dari 72 ibu hamil timester III di RSUP Fatmawati Jakarta, terdapat $26.4 \%$ ibu yang mengalamidepresi ringan dan $6.9 \%$ depresi sedang.

Depresi dalam kehamilan adalah gangguan mood dengan gejala berupa perasaan sedih, lebih sensitif sehingga mudah tersinggung bahkan sampai menangis, gelisah, tidak ada harapan terhadap masa depan, gangguan tidur berupa mimpi buruk atau insomnia, penurunan nafsu makan, penurunan libido, gangguan interaksi sosial, mudah lelah, gangguan mengingat, susah berkonsentrasi, bahkan beberapa ibu mengalami halusinasi sehingga berisiko mencederai diri sendiri dan orang lain disekitarnya(Perry, Hockenberry, Lowdermilk \& Wilson, 2010; Goodman, Parshad \& Kurkarni, 2010).

Penelitian Kusuma (2018) melaporkan bahwa terdapat beberapa tanda dan gejala depresi pada ibu hamil yaitu panik, bingung, takut, cemas, sedih, marah, menangis, menyesali, kurang konsentrasi, gangguan tidur, beban pikiran meningkat, menolak kehamilannya, keinginan menggugurkan kehamilannya, melakukan upaya menggugurkan kehamilan, serta keinginan untuk menyerahkan anaknya kepada keluarga lain/orang lain. Keluhan lain yang dilaporkan ibu adalah keluhan yang berhubungan dengan asupan nutrisi seperti mual, muntah, kurang asupan makanan, penurunan nafsu makan, penurunan berat badan, kurus, pucat, pusing atau sakit 
kepala, dan penurunan tekanan darah.

Menurut Perry, Hockenberry, Lowdermilk dan Wilson (2010); Goodman, Parshad dan Kurkarni (2010), faktor yang mempengaruhi depresi dalam kehamilan adalahfaktor fisik/biologis, faktor psikologis dan faktor psikososial. Faktor fisik/biologis berupa gangguan mood pada masa kehamilan melibatkan patologi sistem limbik, ganglia basalis, hypothalamus dan faktor hormonal. Penyakit ibu saat seperti hipertensi, , hepatitis, HIV, DMG dan lain-lain.

Faktor psikologis yang berkontribusi terhadap kejadian depresi dalam kehamilan adalah wanita dengan tingkat ketergangtungan tinggi biasanya cenderung memiliki harga diri yang rendah, tidak asertif dan menggunakan ruminative coping. Beberapa pakar mengatakan seseorang merasa tertekan akan cenderung fokus pada tekanan yang mereka rasakan dan secara pasif merenung daripada mengalihkannya atau melakukan aktivitas untuk merubah situasi buruk tersebut. Cenderung berfikir irasional yaitu pemikiran yang salah dalam berpikir seperti menyalahkan diri sendiri atas ketidak beruntungan. Hal ini dapat menyebabkan pesimisme dan apatis pada ibu hamil.

Faktor psikososial berupa kegagalan dalam perkawinan, kurangnya dukungan dari pasangan dan orang terdekat lainnya, hubungan yang buruk dengan suami dan mertua, kekerasan dalam rumah tangga, riwayat gangguan afektif seperti riwayat depresi pada kehamilan sebelumnya, riwayat depresi dalam keluarga, gangguan mood saat menstruasi (Fitelson, Kim, Baker \& Leight, 2011; Klainin $\&$ Arthur, 2009).

Faktor lainnya yang dapat menjadi pencetus depresi dalam kehamilan adalah faktor sosial ekonomi berupa gaya hidup misalnya penggunaan zat-zat yang berbahaya terhadap kehamilan seperti rokok, obat-obatan, alkohol, narkotika. Faktor demografi seperti usia ibu, pendidikan, pekerjaan, paritas, budaya atau norma yang berlaku (Fitelson, Kim, Baker \& Leight, 2011; Bloch, et al.,2000).

Penelitian kualitatif yang dilakukan oleh Kusuma (2018) melaporkan beberapa faktor yang menyebabkan terjadinya depresi perinatal yaitu 1) masalah keluarga berupa usia anak yang masih kecil, jumlah anak yang banyak, kurang dukungan suami, kurang dukungan orang terdekat lainnya terutama orangtua dan mertua, gangguan kesehatan anggota keluarga, kurang harmonisnya hubungan ibu dengan suami/pasangan; 2) faktor keuangan keluarga meliputi suami yang tidak memiliki pekerjaan tetap, istri yang tidak bekerja, kehilangan mata pencaharian akibat penghentian kerja, penghasilan/pendapatan keluarga yang rendah serta tingginya biaya hidup sehari-hari; 3) faktor kesehatan ibu meliputi riwayat kesehatan yang lalu seperti DM, hipertensi, tumor payudara, kanker, penyakit tiroid), gangguan obstetrik seperti riwayat persalinan sectio caesarea, panggul sempit, partus lama, dan masalah kesehatan ibu saat ini meliputi demam, flu, batuk, nyeri abdomen dan lain sebagainya); 4) 
faktor demografi ibu berupa usia $>35$ tahun, jumlah, pendidikan, dan pekerjaan ibu.

Depresi dalam kehamilan memberikan dampak buruk kepada ibu dan janin mulai dari masa kehamilan hingga postpartum, serta dampak buruk terhadap keluarga. Dampak depresi terhadap kehamilan antara lain 1) mengganggu pertumbuhan dan perkembangan janin; 2) meningkatkan produksi neuraladrenalin, serotonin, dan gotamin; 3) risiko perdarahan pada masa kehamilan; 4) risiko terjadinya aborsi, kelahiran prematur dan berat badan lahir rendah (Stone \& Menken, 2008; Hendrick, 2006).

Dampak depresi pada masa persalinan antara lain seperti his yang tidak teratur, jalan lahir menjadi kaku, perdarahan intranatal, posisi janin tidak normal (Stone \& Menken, 2008). Dampak depresi terhadap masa postpartum antara lain 1) mengganggu bonding and attachment karena ibu yang mengalami depresi saat hamil biasanya tidak tertarik kepada bayinya, menolak untuk menyusui bayinya serta kurang merespons isyarat bayi seperti menangis atau tersenyum; 2) cenderung tidak mau mendengarkan saran dari tenaga kesehatan atau keluarganya; 3) mengalami beberapa masalah seperti penurunan libido, gangguan tidur berupa susah tidur atau mimpi buruk, gangguan nutrisiyang berdampak kepada penurunan berat badan gelisah, tidak percaya diri dan lainnya (Reeder, Martin \& Griffin, 2012).

\section{METODE PENELITIAN}

Penelitian ini merupakanpenelitian deskriptifdengan populasi adalah seluruh ibu hamil yang ada di Wilayah Kerja Puskesmas Bangkinang yaitu sebanyak 766 orang dan Puskesmas Tapung I sebanyak 484. Penelitian ini dilakukan pada Bulan Juni 2016. Pengambilan sampel dilakukan dengan teknik consecutivesampling. Besar sampel yang dipilihadalah54 ibu hamil yang memenuhi syarat kriteria inklusi, dengan sebaranmasing-masing kecamatan adalah 32 ibu hamildi Kecamatan Bangkinang dan 22 ibu hamil di Kecamatan Tapun I. Pengumpulan data karakteristik ibu hamil menggunakan instrumen demografi sedangkan kondisi depresi yang dialami ibu hamil di ukur menggunakan edinburgh postpartum depression scale (EPDS). EPDS yang digunakan adalah EPDS yang terdiri dari 10 pernyataan,dengan nilai titik potong (cutof point score) 10 , kriteria $<10$ dikatakan tidak depresi dan $\geq 10$ dikatakan depresi(Departement of Health, Goverment of Western Australia, 2006), Wisner). Beberapa penelitian di Indonesia juga melaporkan bahwa EPDS dinyatakan valid dan reliabel untuk mengukurdepresi dalam kehamilan dengan nilai validitas $80,1 \%$ dan reliabilitas $91-94 \%$ (Ismail, 2003), dengan nilai sensitifitas dan spesifisitas mencapai $100 \%$ (The American College of Obstetricians and Gynecologist, 2010). 


\section{HASIL D AN PEMBAHASAN}

Hasil penelitian ini ditampilkan dalam bentuk tabel distribusi frekuensi dan tabel rerata, yang dianalisis dengan analisis univariat, selanjutnya dapat dilihat pada tabeltabel berikut:

Tabel 1. Karakteristik Ibu Hamil di Wilayah Kerja Puskesmas Bangkinang dan Tapung I Tahun $2016(n=54)$

\begin{tabular}{|c|c|c|c|}
\hline \multirow[t]{2}{*}{ No } & \multirow[t]{2}{*}{ Variabel } & \multicolumn{2}{|c|}{ Frekuensi } \\
\hline & & $\mathbf{n}$ & $\%$ \\
\hline 1. & $\begin{array}{l}\text { Usia ibu } \\
\text { 1. Berisiko }(<20 />35) \\
\text { 2. Tidak Berisiko }(20-35)\end{array}$ & $\begin{array}{c}8 \\
46\end{array}$ & $\begin{array}{l}14.81 \\
85.19\end{array}$ \\
\hline 2. & $\begin{array}{l}\text { Pendidikan ibu } \\
\text { 1. Dasar Menengah } \\
\text { 2. PT }\end{array}$ & $\begin{array}{l}37 \\
17\end{array}$ & $\begin{array}{l}68.52 \\
31.48\end{array}$ \\
\hline 3. & $\begin{array}{l}\text { Pekerjaan ibu } \\
\text { 1. Tidak Bekerja } \\
\text { 2. Bekerja }\end{array}$ & $\begin{array}{l}28 \\
26\end{array}$ & $\begin{array}{l}51.85 \\
48.15\end{array}$ \\
\hline 4. & $\begin{array}{l}\text { Kehamilan keberapa } \\
\text { 1. Primigavida } \\
\text { 2. Multigravida }\end{array}$ & $\begin{array}{l}33 \\
21\end{array}$ & $\begin{array}{l}61.11 \\
38.89\end{array}$ \\
\hline 5. & $\begin{array}{l}\text { Riwayat abortus } \\
\text { 1. Tidak pernah } \\
\text { 2. Pernah }\end{array}$ & $\begin{array}{c}48 \\
6\end{array}$ & $\begin{array}{l}88.89 \\
11.11\end{array}$ \\
\hline 6. & $\begin{array}{l}\text { Kehamilan } \\
\text { 1. Tidak diinginkan } \\
\text { 2. Diinginkan }\end{array}$ & $\begin{array}{l}15 \\
39\end{array}$ & $\begin{array}{l}27.78 \\
72.22\end{array}$ \\
\hline
\end{tabular}

Tabel 1 menggambarkan bahwa sebagian besar ibu hamil yang menjadi responden pada penelitian ini adalah melahirkan pada usia tidak berisiko (20-35 tahun), telah menempuh pendidikan formal dengan kategori pendidikan dasar menengah (SD, SMP/sederajat dan SMA/sederajat), tidak memiliki pekerjaan lain (ibu rumah tangga), sebagian besar adalah ibu dengan kehamilan pertama kali (primigravida),tidak pernah mengalami abortus, dan kehamilannya diinginkan.
Tabel 2. Rata-Rata Jumlah Anak Hidup yang Dimilikioleh Ibu $(n=54)$

\begin{tabular}{cccc}
\hline Variabel & Mean & Min & Maks \\
\hline Jumlah anak hidup & 1.22 & 0 & 3 \\
\hline
\end{tabular}

Tabel 2 menggambarkan bahwa, rata-rata ibu telah memiliki 1.22 orang anak hidup, dengan jumlah anak paling sedikit adalah 0 orang dan jumlah terbanyak 3 orang anak.

Tabel 3. Kondisi Depresi pada Ibu Hamil $(n=54)$

\begin{tabular}{lcc}
\multicolumn{1}{c}{ Kejadian Depresi } & \multicolumn{2}{c}{ Frekuensi } \\
\cline { 2 - 3 } & $\mathbf{n}$ & $\mathbf{\%}$ \\
\hline a. Depresi & 10 & 18.52 \\
b. Tidak Depresi & 44 & 81.48 \\
\hline Total & 54 & 100.00 \\
\hline
\end{tabular}

Tabel 3 menggambarkan bahwa dari54 ibu hamil yang menjadi responden pada penelitian ini, terdapat sebanyak 10(18.52\%) ibu yang mengalami depresi pada masa kehamilannya.

Tabel 4. Karakteristik Ibu Hamil yang Mengalami Depresi $(\mathbf{n}=10)$

\begin{tabular}{lll}
\hline No & Variabel & \multicolumn{2}{c}{ Frekuensi } \\
\cline { 2 - 3 } & n & $\%$
\end{tabular}

1. Usia ibu

a. Berisiko $(<20 />35) \quad 6 \quad 60.00$

b. Tidak Berisiko (20-35) $4 \quad 40.00$

2. Pendidikan ibu
a. Dasar Menengah
80.00
b. PT
20.00

3. Pekerjaan ibu
a. Tidak Bekerja
50.00
b. Bekerja

$5 \quad 50.00$

4. Kehamilan keberapa
a. Primigavida
$3 \quad 30.00$
b. Multigravida
$7 \quad 70.00$

5. Riwayat abortus
a. Tidak pernah
$9 \quad 90.00$
b. Pernah
$1 \quad 10.00$

6. Kehamilan
a. Tidak diinginkan
330.00
b. Diinginkan
$7 \quad 70.00$

Tabel 4 menggambarkan bahwa, sebagian besar depresi terjadi pada ibu hamil dengan usia risiko tinggi (risti), berpendidikan dasar 
menengah (SMA), depresi terjadi pada ibu yang tidak bekerja (IRT) dan bekerja, kehamilan multigravida, tidak pernah mengalami abortus, dan beberapa ibu yang mengalami depresi disebabkan oleh kehamilan yang tidak diinginkan.

Hasil penelitian ini menggambarkan bahwa kejadian depresi yang dialami oleh ibu hamildi Kecamatan Bangkinang dan Tapung I cukup tinggi. Kendal dan Kantor (dalam Beck, 2003) menekankan bahwa depresi dalam kehamilan harus ditekan menjadi $1 \%$ bahkan dihilangkan.

Kejadian depresi pada penelitian ini diduga disebabkan oleh faktor usia ibu, dimana sebagian besar ibu berada pada risiko tinggi. Berpendidikandasar menengah (SD, SMP, SMA/sederajat, primigarvida, jumlah anak hidup dan faktor kehamilan yang tidak diinginkan karena beberapa ibu tidak menginginkan kehamilannya. Secara rinci, kejadian depresi tersebut dapat dilihat pada tabel berikut:

Tabel 5. Karakteristik Ibu Hamil yang Mengalami Depresi dalam Kehamila

\begin{tabular}{cccccccc}
\hline No & Usia Ibu & Pendidikan & Pekerjaan & $\begin{array}{c}\text { Kehamilan } \\
\text { Ke }\end{array}$ & $\begin{array}{c}\text { Anak } \\
\text { Hidup }\end{array}$ & $\begin{array}{c}\text { Riwayat } \\
\text { Abortus }\end{array}$ & $\begin{array}{c}\text { Diinginkan/ } \\
\text { tidak }\end{array}$ \\
\hline 1 & Risti & SMA & IRT & 1 & 0 & Tidak & Diinginkan \\
2 & Risti & SMA & Pedagang & 4 & 3 & Tidak & Tidak Diinginkan \\
3 & Risti & SMA & Wiraswasta & 1 & 0 & Tidak & Diinginkan \\
4 & TidakRisti & SMP & IRT & 4 & 3 & Tidak & Tidak Diinginkan \\
5 & Tidak Risti & PT & Honorer & 1 & 0 & Tidak & Diinginkan \\
6 & Risti & SD & Pedagang & 4 & 3 & Tidak & TidakDiinginkan \\
7 & Risti & SMP & IRT & 3 & 2 & Tidak & Diinginkan \\
8 & Risti & SMP & Pedagang & 4 & 2 & Pernah & Diinginkan \\
9 & Tidak Risti & PT & IRT & 2 & 1 & Tidak & Diinginkan \\
10 & Tidak Risti & SMP & IRT & 2 & 1 & tidak & Diinginkan \\
\hline
\end{tabular}

Penelitian ini didukung oleh penelitian Fitelson, Kim, Baker dan Leight (2011), Klainin dan Arthur (2009), Stone dan Menken (2008), Hendrick (2006), Cohen dan Nonac (2005) yang mengatakan bahwa faktor-faktor yang berkontribusi menyebabkan depresi pada masa perinatal adalah pendidikan, pekerjaan, paritas.

Penelitian Rojas, Fritsch, Guajardo, Barroilhet dan Jadresic (2010), melaporkan berbagai faktor yang menyebabkan depresi postpartum yaitu faktor sosial demografi, kehamilan yang tidak direncanakan atau tidak diinginkan.Penelitian Beck, 2001 (dalam Beck \& Driscoll, 2006) melaporkan dari 13 penyebab depresi postpartum salah satu diantaranya adalah kehamilan yang tidak diinginkan (Beck \& Driscoll, 2006).

Penelitian kualitatif Kusuma (2018) melaporkan beberapa faktor yang menyebabkan terjadinya depresi perinatal yaitu 1) masalah keluarga berupa usia anak yang masih kecil, jumlah anak yang banyak, kurang dukungan suami, kurang dukungan orang terdekat lainnya terutama orangtua dan mertua, gangguan kesehatan anggota keluarga, kurang harmonisnya hubungan ibu dengan suami/pasangan; 2) faktor keuangan keluarga meliputi suami yang tidak memiliki pekerjaan tetap, istri yang tidak bekerja, kehilangan mata pencaharian akibat penghentian kerja, penghasilan/pendapatan keluarga yang rendah serta tingginya biaya hidup sehari- 
hari; 3) faktor kesehatan ibu meliputi riwayat kesehatan yang lalu seperti DM, hipertensi, tumor payudara, kanker, penyakit tiroid), gangguan obstetrik seperti riwayat persalinan sectio caesarea, panggul sempit, partus lama, dan masalah kesehatan ibu saat ini meliputi demam, flu, batuk, nyeri abdomen dan lain sebagainya); 4) faktor demografi ibu berupa usia >35 tahun, jumlah, pendidikan, dan pekerjaan ibu.

Perawat sebagai care giver bagi ibu perinatal diharapkan mampu memberikan asuhan keperawatan yang holistik, sehingga berbagai masalah psikologis pada masa perinatal dapat dicegah. Upaya tersebut sudah diterapkan dalam pelayanan antenatal terpadu, melalui pemeriksaan kehamilan, Kelas Ibu Hamil serta pelaksanaan senam hamil. Selain upaya tersebut, dilakukan juga berbagai pengembangan model keperawatan dalam upaya pencegahan depresi pada masa perinatal.

Salah satu model tersebut dikembangkan oleh Kusuma (2017) yang melaporkan bahwa paket edukasi pada Model Pencegahan Depresi PostpartumRatu terbukti efektif menurunkan 60\% depresi yang dialami oleh ibu perinatal.

Menurut St.John dan Emmanuel (2010), kemampuan adaptasi ibu hamil sangat dipengaruhi oleh peran tenaga kesehatan baik melalui pertimbangan personal, menjalin hubungan, melalui pelayanan sosialdan pemberian pendidikan kesehatan. Teori Green mengatakan bahwa baik atau buruknya perilaku seseorang terhadap suatu hal, dipengaruhi oleh pengetahuannya tentang sesuatu hal tersebut (Notoatmodjo, 2012).

\section{SIMPULAN}

Depresi yang dialami ibu hamil di Kecamatan Bangkinang dan Tapung I cukup tinggi, hal tersebut diduga disebabkan faktor usia ibu, dimana sebagian besar ibu berada pada risiko tinggi. Berpendidikandasar menengah (SD, SMP, SMA/sederajat, primigarvida, jumlah anah hidup dan faktor kehamilan yang tidak diinginkan karena beberapa ibu tidak menginginkan kehamilannya.

\section{SARAN}

Disarankan kepada perawat sebagai care giver bagi ibu perinatal diharapkan mampu memberikan asuhan keperawatan yang holistik, sehingga berbagai masalah psikologis pada masa perinatal dapat dicegah.

\section{DAFTAR PUSTAKA}

1. Beck. C.T., \& Driscoll, J.W. (2006). Postparum mood and anxiety disorder: A Clinician's Guide. Canada: Jones and Bartlett.

2. Beck, C.T., Reynold, M.A., \& Rutoewski, R. (2003). Maternity blues and postpartum depression. Journal of Obstetric Gynecologic and Neonatal Nursing, 21(4). 4248.

3. Cohen, L.S., \& Nonacs, R.M. (2005). Mood and anxiety disorder during pregnancy and postpartum (4th ed.). Washington D.C: American Psychiatric Publishin. Inc.

4.Fitelson, E., Kim, S., Baker, A.S., \& Leight, K. (2010). Treatment of postpartum depression: Clinical, psychological pharmacological options. International Journal of Women's Health, 3, 1-14.

5. Hendrick, V. (2006). Psychiatric adisorder in pregnancy and the postpartum: Principle and traetment. Totowa, New Jersey: Humana Press. 
6. Ismail, R.I. (2003). Stress before \&during pregnancy increased risk antepartum depression. Med $J$ Indones, 12 (2).

7. Klainin, P., \& Arthur, D.G. (2009). Postpartum depression in asia cultures:A literature review. International Journal of Nursing Studies, 1355-1373.

8. Kusuma, R. (2017). Efektifitas Model Pencegahan Depresi Postpartum-Ratu terhadap Pencegahan Postpartum. Disertasi Program Doktor Ilmu Keperawatan Univesrsitas Indonesia, Depok.

9. Kusuma, R. (2018). Studi kualitatif: Pengalaman adaptasi ibu hamil. Jurnal Akademika Baiturrahim, 7 (2), 148-164).

10. Notoatmodjo, S. (2012). Promosi kesehatan teori \& aplikasi. Jakarta: Rineka Cipta.

11. Nursanti, I. (2012). Hubungan penyakitjantung dalam kehamilan dan tingkat pendapatan selama kehamilan dengan tingkat depresi pada ibu hamil trimester III di Praktik Kebidanan dan Kandungan RSUP

12. Fatmaawati 2010. Jurnal Kedokteran dan Kesehatan, UIN Syarif Hidayatullah Jakarta, 70 (28).

13. Reeder, S.J., Martin, L.L., \& Griffin, D.K. (2012). Keperawatan maternitas: Kesehatan wanita, bayi dan keluarga (edisi 18.) (Yati Afiyanti., Imami Nur Rachmawati., \& Sri djuwitaningsih, Penerjemah.). EGC: Jakarta.

14. Rojas, G., Fritsch, R., Guajardo, V., Rojas, F. Barroilhet, S., \& Jadresic, E. (2010). Characteristik of depression mothers in the postpartum.Rev Med Chile, 138, 536-542.
15. Stone, S.D., \& Menken, A.E. (2008). Perinatal and postpartum mood disorder's: Perspectives and Treatment Guite for Health Care Practicioner. New York: Springer Publishing Company.

16. The American College of Obstetricians and gynecologists. (2010). Screening for depression during and after pregnancy. Women Health Care Physicians, 453. 